\title{
Humanitarian Protection of Women in Armed Conflicts
}

Iman Zhianpour

MA student of international law, Shahid Ashrafi Esfahani University

\author{
Alireza Arashpour
}

Assistant Professor of law, University of Isfahan (corresponding author)

Mohsen Shekarchizadeh

Assistant Professor of law, Islamic Azad University, Najafabad Branch

\section{Doi:10.5901/mjss.2015.v6n3s2p40}

\section{Abstract}

Throughout history, women have suffered most from armed conflicts in different forms. Thus, humanitarian law observes protective mechanisms for civilians specially women during armed conflicts. Despite protections and actions of international and non-international organizations, there are not enough guarantees to enforce protection of women in armed conflicts. In this regard, this study, entitled Humanitarian protection of women in armed conflicts, made an attempt to explore the related international documents. To do so, the conceptual framework of the study was first set up, defining concepts of war, the law of war, humanitarian law, civilian and protection of civilians. Then, kinds of protections, especially protection against sexual acts of violence, were explored under the title of women in armed conflicts. Finally, the question of whether the current support mechanisms are capable enough to protect women at the time of armed conflicts was discussed. As a conclusion, it can be said that the quality of providing or not providing humanitarian protection of women depends on controlling abundant variables including cultural factors (beliefs, principles, and national norms), psychological factors (policy-makers' tendencies and spirits), international factors (location and regional and international ties), social factors (national manner, ethnic structure, social history, minorities' situation, gender relations), political factors (government's structure and history, state/nation relations) and the relation between these factors as well.

Keywords: Armed conflicts, Humanitarian law, Women

\section{Introduction}

Violence against women continues to persist as one of the most heinous, systematic and prevalent human rights abuses in the world. It is a threat to all women, and an obstacle to all our efforts for development, peace and gender equality in all societies. ... Violence against women is always a violation of human rights; it is always a crime; and it is always unacceptable. Let us take this issue with the deadly seriousness that it deserves -- not only on this International Day, but every day.

This was a part of the message of UN Secretary-General Ban Ki-moon for the International Day for the Elimination of Violence against Women, observed Sunday, November 25. As the content of the message shows, women are of those groups who, at the time of armed conflicts, fall under the aegis of public and private regulation of human rights and humanitarian law; however, their rights have been violated repetitively in these conflicts, weather domestic or international. This study is conducted in response to this general concern and seeks to enrich the knowledge of this domain and, if possible, presents a solution for the realization of these treaties.

\section{Statement of the Problem}

Due to their particular situation, women suffer the most from the impacts and aftermaths of the wars and they are sometimes the target of the most heinous acts as in Rwanda ${ }^{1}$, where, from 1994 to 1995, the number of women who

${ }^{1}$ Rwanda, officially the Republic of Rwanda, is a sovereign state in central and east Africa. Its capital is Kigali and the genocidal mass slaughter of Tutsi took place in 1994 in this country. 
were raped during the civil war was over 175,000. In this regard, the humanitarian law observes some support mechanisms for individuals, women and children in particular, from the start of armed conflicts till the end. To support civilians, especially women, the international humanitarian law deals with the rights and responsibilities of the two parties involved in the conflict, specially the rights of civilians, supporting those who are not involved in the conflict. Consequently, women, like civilians, have benefited from the international humanitarian law which imposes some limits on the ways of conflicts (Krill, 2008). Due to particular needs of individuals, especially women, this law has assigned International Committee of the Red Cross as its guardian to ensure law enforcement. This study is carried out in this regard with the same concern and with an academic approach to explore the issue of the humanitarian protection of women in armed conflicts. Reviewing international documents on armed conflicts, the researchers sought to compile and classify the kinds of protection mechanisms for women and inspect their application. In other words, this study was to answer the following questions:

1. What are the kinds of law and support mechanisms for women in international documents and treaties?

2. What are the examples of violations of women's rights in recent conflicts?

3. Are the current support mechanisms capable enough to protect women at the time of armed conflicts?

\section{Methodology}

Research in humanities is done within three paradigms of positivism, interpretivism and critical. In terms of methodology, all paradigms which are not positivist are placed in qualitative methodology. Qualitative research is generally defined as a research methodology in which the finding is not obtained through statistical analysis with the intent of quantifying data. Data, in this kind of research, is collected through observation, interview, or exploring documents. This study was carried out within the second research paradigm, namely interpretivism. More specifically, through exploring documents, it was tried to find the international documents related to humanitarian law set to protect women in times of armed conflicts. The data traced and extracted from official texts including documents, treaties, resolutions, advisory opinions and literary texts, memoirs, biographies, essays and writings available in the media was detailed and compiled using analytical descriptive method to meet the aims of the study and provide an answer to the research questions.

\section{The Conceptual Framework of the Study}

\subsection{Conflict (war)}

War has been the most important linkage between nations since the beginning of recorded history, that is, 4,000 BC up to the present. The outbreak of wars has caused human casualties and financial damage (Ziaie Bigdeli, 2013). This problem is so continuous that Richard E. Smalley, the Noble Prize winner in Chemistry in 1996, presented war as the sixth problem, after energy, water, food, environment and poverty, in a list entitled Top Ten Problems of Humanity for Next 50 Years. Henderson, quoting from Beer, believes that 14,500 wars have taken place from 3,500 BC to the end of the $20^{\text {th }}$ century, as a result of which 3.5 billion people have lost their lives and only 300 years of human history have been spent in peace (Henderson, 2010).

\subsection{Law of war}

War and bloodshed has been deprecated in all cultures and every effort has been made since ancient history to regulate it, out of which ancient texts like Mahabharata and the Code of Hammurabi are worth mentioning. Holy books like the Old Testament and Quran have predicted some regulations on respecting the rival and the other party of the conflict. In general, different thinkers, since Middle Ages, have come up with various theories, including just war (jus bellum), jus ad bellum or right to war and right at war; however, it was Saint Petersburg Declaration of 1868 which set forth the prohibition of unnecessary suffering for the first time. The declaration stipulates 'that the only legitimate object which States should endeavor to accomplish during war is to weaken the military forces of the enemy' (Ramezani Ghavamabadi, 2010). Consequently, communities endeavor to humanize the war phenomenon as much as possible in general and the importance of conflict and the ways of its prevention for the lawyers of International Law has led to setting forth the issue of Law of War.

Law of War consists of a set of international law regulations governing the mutual relations of belligerent countries in an international armed conflict or between belligerent and neutral countries. The parties involved in such a conflict are bound to observe the regulations during their belligerent operations (Ziaie Bigdeli, 2001). Law of War contains regulations 
to bring the leading and controlling of armed conflicts under legal order, humanize them and reduce their damaging and devastating effects (Ziaie Bigdeli, 2013).

\subsection{Humanitarian law}

The concept of Humanitarian Law has replaced the concept of Law of War in general or the concept of "the Law of Armed Conflict" in a more comprehensive way (Ghorbannia, 2011). Humanitarian Law is one of the oldest branches of public international law (Zamani, 1999) and in its most general and classic definition it "refers to international regulations that seeks to alleviate human pains caused by war" (Solis, 2010, 22). In other words, "humanitarian law is a set of international customary or conventional laws which specifically monitors the belligerent forces conduct in international or non-international armed conflicts; it is a branch of public international law governing the use of armed force and treatment of persons during an armed conflict" (Ghorbannia, 2011).

Humanitarian law "on the one hand, is a branch of international human rights, and on the other hand, is a branch or aspect of the Law of War or the international law of armed conflicts" (Ziaie Bigdeli, 2001). It can also be claimed that humanitarian law "is considered a developed or reinforced form of traditional international law of war (Rights of War). In this regard, today, most of war regulation includes those international armed conflicts which the involved parties do not consider as war. The term "International Humanitarian Law" refers to this shift" (Fleck, 2012, 29).

What nowadays is recognized as international humanitarian law consists of two branches of law applicable in armed conflicts: law of Hague and law of Geneva. Law of Hague specifies in particular regulations concerning the laws and customs of war on land and belligerents' rights and tasks in military operation, limiting the parties' right of choosing and using tools and ways and instruments of damaging the enemy in an international armed conflict. It protects people, properties and objects which have been damaged or will be damaged in hostilities. Law of Geneva protects war victims and intends to provide guarantee for non-combatants and members of armed forces who have laid down their arms and those placed hors de combat. It consists of conventions of 1864, 1906, 1929 and especially 1949. Although these two branches of law continued to develop separately, they gradually formed an integral combined system in whose modification two amendment protocols of 1977 played a significant role ${ }^{2}$ (Ghorbannia, 2011)

\subsection{Civilian}

According to principle of distinction in customary humanitarian law, the belligerents must distinguish between civilians and combatants. Attacks can be carried out only against combatants. Attacks must not be directed against civilians (Henckaerts \& Doswald-Beck, 2008). Differentiating between military personnel ${ }^{3}$ and civilians is an example of international community's effort to protect people who are not directly involved in armed conflict against its perils and damaging effects (Pourmohammadi, 2012). Principle of distinction between civilians and combatants was first laid down in Saint Petersburg Declaration of 1868, stipulating that "that the only legitimate object which States should endeavor to accomplish during war is to weaken the military forces of the enemy" (Henckaerts \& Doswald-Beck, 2008, 62). This distinction was also emphasized in non-international armed conflicts.

According to the second rule of the principle of distinction in customary humanitarian international law, acts or threats of violence the primary purpose of which is to spread terror among the civilian population are prohibited. States' practice considers this rule applicable in both international and non-international armed hostilities as a customary international law rule (Henckaerts \& Doswald-Beck, 2008).

To clarify the legal setting of civilians, the fifth rule of principle of distinction in customary humanitarian international law can be helpful. According to the rule civilians are those who are not members of military personnel. Civilian population involves all the civilians (Henckaerts \& Doswald-Beck, 2008). Therefore, civilians include all the human beings who are in the territory of the parties in conflict and are not a member of armed personnel, including regular or irregular combatant (Ziaie Bigdeli, 2013).

\footnotetext{
2 Protocol III relating to the Adoption of an Additional Distinctive Emblem was ratified in 2005.

${ }^{3}$ Some texts distinguish between military and combatant with close attention to the diction and some take it with ease. What international humanitarian law emphasizes is the issue of combatants not the military personnel. For instance, according to the third principle of distinction in customary humanitarian international law, a doctor or priest can be a member of the military personnel; however, he is not necessarily a combatant.
} 


\subsection{Protecting civilians}

Protecting civilians is meaningful in the context of the sixth rule of principle of distinction in customary humanitarian international law, according to which civilians are protected against attacks unless and until they participate directly in the hostilities (Henckaerts \& Doswald-Beck, 2008). Based on the document of "interpretive guide to the concept of direct participation in armed conflicts from humanitarian international law viewpoint" provided by International Committee of Red Cross in 2009, direct participation means the special belligerent acts carried out by persons as a part of hostilities between the two parties involved in international or non-international conflict. The components of direct participation include damage threshold, direct cause and belligerent contact (Ziaie Bigdeli, 2013).

\subsubsection{Public protection of all civilians}

By public protection we mean all the humanitarian affairs, tasks and actions the aim of which is to protect all civilians against the dangers of armed conflict, both international and non-international, to help them to get over the direct effects of the war and to provide them with the necessary conditions of resettlement. The base of granting public protection is the vulnerability of all civilians. As a result, the higher goes their vulnerability, falling under the category of special persons (such as children and women), the more they are protected. In the other words, beside public protection, they enjoy specific protection as well (Ziaie Bigdeli, 2013).

\subsubsection{Specific protection of some of the civilians}

In regard with granting public protection to civilians and their vulnerability, some more vulnerable people like women and children fall under the category of specific persons and benefit from specific protection as well. In other words, apart from primary and public protection in armed conflicts, due to their gender, age and spiritual and physical conditions, some groups of persons need more protection than other civilians. What is more significant is the fact that, among these specific groups, some persons like pregnant women are in need of more special protection. Despite the fact that some legal texts list these groups as foreigners, refugees, people without citizenship, women, children, journalists, detainees and other civilians, because of the emphasis of this study on women, we continue discussing women.

\section{Women in Armed Conflicts}

Culture of violence against women and girls has been prevalent in all societies through all time. However, this problem has become more highlighted with the outbreak of war flames and armed hostilities. Consequently, women and violence against them is of those issues that, in recent decades, has seriously attracted a great deal of international organizations including the four treaties of Geneva, added protocols, the UN bodies such as the General Assembly and its resolutions and reports, the Security Council and its various resolutions (thematic or case), human rights organizations like world conferences of human rights, Human Rights Commission and Council, Human Rights Committee, regional organizations like the African Union, and the charts of criminal courts such as the international court for the former Yugoslavia, the international court for Rwanda and special court for Sierra Leon and International Criminal Court. This issue has been in the spotlight since 1990s, when international and domestic armed conflicts increasingly spread, leading to widespread violence against thousands of innocent women and children.

Apart from international human rights support and general protection of civilians stipulated in humanitarian international law, women enjoy other specific supports, too. To be exact, some women, due to their particular situation, benefit from specific supports as well as general supports. Therefore, protection of women against armed conflicts falls under two categories: general protection of women and specific protection of some women (Ziaie Bigdeli, 2013).

\subsection{General protection of women}

Every woman without exception has the following protections:

1. Women must be protected against any violation and be respected by the parties of the conflict in all time and places and in all forms of armed conflicts. Their special protective, health and aid requirements affected by the conflicts must be respected.

2. Women are protected against any damage to their honor particularly against any sexual violence including rape, enforced prostitution and other forms of desecration and disgraceful violation and contemptuous 
treatment. All the aforementioned acts are under absolute prohibition.

In addition, the chart of International Criminal Court has included, apart from the above acts, sexual slavery, forced pregnancy and enforced sterilization of women within the war crimes (Ziaie Bigdeli, 2013).

\subsection{Specific protection of some of the women}

A group of women enjoy additional or complementary protection, as well as general protection, the most important of which include protection of pregnant women and mothers of under-seven-year-old children, preferential or national treatment with pregnant women and mothers of under-seven-year-old children who are of foreign nationality and live in the land of one of the parties of the conflict, preferential treatment with and specific protection of women who are giving birth and also nursing mothers when distributing aid packages, evacuating women from surrounded areas, immunity of nursery from military attack, protecting transport vehicles of women who have just given birth, traffic freedom for any clothes, provisions, and nutrient foods necessary for pregnant women and those who have just given birth, protecting the detainee women or those prevented from freedom by separating women's detention center from men's, particularly their sleeping place and health facilities, hospital and medical care for pregnant women and women who have just given birth in detention center, receiving food proportionate with these women's physical needs, being frisked by the same gender, legal investigation with pregnant women and mothers having priority, preventing death sentence and execution of pregnant women and mothers of dependent infants (Ziaie Bigdeli, 2013).

\subsection{Women and rape}

In our time, rape is a kind of Guerrilla warfare in ethnic wars. Nothing can destabilize the ethnic enemy with such an impact more than raping women. More than half of the raped women in interracial wars are the victims of violators whom they had known before or whom they had met within a 60 kilometer radius. Nearly half of the responding women admit that the men who raped them lived in their villages or the nearby villages. Almost a quarter of responding women knew their rapist(s). Apparently, half of the women who married men from other races were raped by the men from their own races to be punished for this interracial marriage. For a new combatant, raping his ethnic enemy's wife tastes the flavor of an absolute victory over the rival. Woman's body is the emblematic of resistance in interracial wars. The new warrior rapes to shatter the resistance, thinking that by doing so he strikes the crushing blow to his rival. Having concealed his wife, daughter, mother and sister somewhere safe, he goes to seek his rival's wife, daughter, mother and sister. The fighters do not rape because of uncontrolled passion or sex complex. Rape is a military strategy to weaken enemy's spirits. In European interracial wars, rape is equivalent of destroying enemy's home, church or temple, cultural heritage and values (Visniec, 2012). These lines from taken from the drama "Woman's Body like Battleground in Bosnian War" depicts, with a tragic tone, women's situation in nowadays wars.

Of the hot international issues is the systematic rape of women in armed conflicts which is barbarously conducted with the aim of racial extermination (Mo'zenzadegan, Heidari, \& Nikoomanzari, 2013). In one of the reports of UN Women organization given in July 2013 , it has been declared that plenty of women have been abducted by military men in recent events in Mali and then have been raped.

The $20^{\text {th }}$ century witnessed a great and vast change in humanitarian international law regarding raping women at the time of war (Khak, 2008). Part of this change goes back to the horrendous calamities carried out against women in this century. For instance, during World War I, Wilhelm II's soldiers and the Nazi Army raped thousands of women in Belgium. This horrible crime was not without purpose. On the contrary, this was carried out systematically and was used as weapon to cause shock and horror in Belgium and other enemy countries of Germany (Azizi, 2014). In addition, during World War II, about 100,000 to 200,000 women were systematically employed or abducted and, by treating them savagely, were forced to sexually serve Japanese soldiers as "comfort women". Although $80 \%$ of these women were Korean (Korea was then one of Japan's colonies), they also included women from Japan, the Philippines, China, Indonesia and Europe. It was supposed that each woman serve about 30 soldiers a day and receive a low wage or nothing at all (Mo'zenzadegan, Heidari, \& Nikoomanzari, 2013).

A great deal of reports was given on the Soviet Army raping women and girls in Germany, Hungary, Bulgaria and Yugoslavia. The intense and violence of the Soviet soldiers was so high that few women escaped the rape crime. It's claimed that more than a million women were raped in Germany and in Eastern Germany in particular. Some believe that this systematic rape was done by the Red Army to racially dishonor German women, whom were regarded as the noble race by Reich III. The public rape of women by the Red Army was considered the greatest crime of history against women. According the estimate of a book named "The Fall of Berlin in 1945" by Antony Beaver, around 7.3\% of children 
born in Berlin between 1945 and 1946 had Russian fathers. Antony Beaver writes that the Russian, from their very entry into Germany, started their systematic rape and in some villages raped all the women from 10 to 80 years old (Azizi, 2014).

In Bosnian War (1992-1995), the most injuries were done to the Bosnian women and children. In this war, which is the greatest genocide in Europe after World War II, Serbian and Croatian soldiers separated Muslim women and even Serbian and Croatian women who had married Muslim men. According to the figures published by the Bosnian state in late September 1992 and the existent reports from former Yugoslavia, at least 20,000 women were raped by the Serbs, the most of which were carried out in the presence of other family members or the villagers. Another report prepared by the EU truth-seeker delegation in December 1992, states that the Serbian soldiers have raped 25,000 most of which were of Muslim ethnicities. The report points out that "in recent months, this act was a part of a conscious pattern of sexual abuse according to which rape was not accidental or haphazard but was employed per se at the service of a strategic purpose" (report of the EU investigation committee on treatment of Muslim women in former Yugoslavia).

It's been estimated that about 250,000-500,000 Tutsi women and girls were sexually abused in Rwanda from April of 1994 to April of 1995. In addition to serious mental problems, women who fall victim to such a crime contract diseases like AIDS and intercourse diseases and give birth to unwanted children, the number of which is estimated to be around 2,000 to 5,000 in current Rwanda. Due to abortion prohibition in Rwanda (or the impossibility of doing it in a timely manner) some women kill the baby after being born and some cause schism and disagreement in family by keeping the baby. Also, with their husbands and fathers being killed, a lot of these women cannot afford to pay the cost of living of these children who are granted the terms like "children of bitter memories", "children of hatred, or "unwanted children" (Mo'zenzadegan, Heidari, \& Nikoomanzari, 2013).

According to official statistics, 47 women are raped every hour during civil war in the Democratic Republic of Congo, where is known as the worst place for women in the world. The UN has reported that about 15,000 women were raped in Eastern Congo in 2009 and 2010 and states that these figures are estimated. This collective bitter experience has found its way in language and culture in a way that the idiom "taken into the forest" refers to being raped.

The Syrian civil war which commenced in 2010 led to people took refuge in groups of 10,000. Out of 8 million Syrian refugees, at least 2 million and 400 thousand have taken refuge in other countries and the rest are wandering around the country. Women consists more than half of these figures. Rape and sexual abuse of women, social insecurity and violence against women are the aftermath of such massive exodus and wandering. There are documented reports in all the countries receiving the Syrian refugees about sexual violence, threatening and intimidating women, forcing to prostitution, rape, forced marriage with girls and sexual slavery of women. In Alza'atry camp in Jordan, the biggest refugee camp of Syrians with the population of 125,000 , there have been formed networks of organized crime, whose activities consist of raping women and then forcing them to prostitute, abducting and intimidating them. Out of one million Syrians living in Turkey, most of those living outside the refugee camps do not have identity papers. Women and girls being raped are not willing to report. The non-governmental organization named "Refuge", whose center is in Diyarbakir and was founded in 2001, has some documents containing interviews with Syrian refugee women which reveals hundreds of cases of rape by the Turkish officers and military.

In a widespread study on sexual violence against Syrian refugee women which was carried out in 2013 with the cooperation of the UN Women Organization, the Norwegian Refugees Society, the Law and Political Sciences College of Salahiddin University in Kurdistan, Iraq and Waroyn Foundation for Women's rights, more than $63 \%$ of women admitted that they had been subject to sexual violence including dishonoring, beating, sexual harassment, enforced sexual intercourse, threatening, intimidating and rape. A number of these acts of violence were done by the men who worked in different sections of the UN, international and national organizations, officers issuing identity papers for the refugees and those in charge of refugees' affairs. The participating women had settled in Domiz camp and in Erbil, Dehuk and Süleymaniye. The irony of this massive violation in Kurdistan of Iraq is the fact that the Kurds themselves were the victims of one of the greatest genocides of the century with 182,000 victims and thousands of cases of rape against women during Baath reign in Iraq in 1980s.

And finally in Iraq, the ISIS, which is a terrorist armed group, attacked Shingal at the night of August 1, 2014 and captured the town. Having raped women, they took Christian and Yazidi women to one of the bazaars of Mussel to sell them as war slave. ISIS in Mussel and Shingal, consider women their own plunder and have no respect and honor for them. They publish pictures of their gang raping Shia and Yazidi girls on the net to take advantage of this sexual horrification as a winning card in war of nerves. 


\subsection{Women and protection against sexual violence}

From international law point of view, sexual violence and its most important form, i.e. rape, has been stipulated as the example of war crime, also as one of the crimes against humanity and as one of the examples of torturing in the statute of Criminal International Court. Based on the verdict issued by the criminal court of Rwanda in "Akayesu" case, sexual violence means "any act of sexual characteristic done against a person in a compulsory situation and manner" (Akayesu Case, 1998, 688; cf. Akhgari Bonab, 2009, 194). Sexual violence is not limited to sexual assault on physical integrity of a person and it might include acts that do not involve sexual intercourse or the smallest physical contact.

Additionally, explaining sexual violence, the criminal court of Rwanda in its verdict on Furundzija Case clearly mentions this fact that in realization of sexual violence physical contact is not a condition: "important sexual violence which is even less than sexual intercourse is punishable. This prohibition includes all the cases of abuse and illegitimate sexual use done against physical, ethical and spiritual integrity of a person by way of force, threat to use force or hoorifii, leading to insulting and humbling the victim's personality (Furundzija Case, 1998, 168; cf. Akhgari Bonab, 2009, 194). Generalizing the concept of sexual violence to mental injuries and attacks can be seen in the report of special reporter of the commission of preventing discrimination and protection of minorities in report "Forms of Contemporary Slavery". In the report, sexual violence is defined as follows: "sexual violence includes physical and spiritual attacks done on the sexual characteristics of a person such as forcing the person to get naked in public, injuring a person's private parts, or cutting women's breasts."

\subsection{Criminalizing sexual violence and related criminal terms}

As was mentioned above, sexual violence is subject to criminalize under various legal terms according to international criminal law. In addition, it is stipulated in Security Council resolution number 1820 that sexual violence has criminal terms of crime against humanity, war crimes and torture. These terms have been taken into account in the statute of International Criminal Court and sexual violence has been criminalized under such terms (Akhgari Bonab, 2009).

The statute of International Criminal Court, article 7 has described "rape, sexual slavery, enforced prostitution, forced pregnancy, enforced sterilization and any other kind of sexual violence of such proportions" as crimes against humanity and has put it among crimes subject to the court's jurisdiction. Article 8 of the statute on "war crimes" lists committing these acts, both in international armed conflicts and domestic armed conflicts, as war crimes and subject to prosecute, trial and punishment in International Criminal Court, particularly when they are carried out in a program or policy or in a comprehensive manner (Momtaz \& Ranjbaran, 2008). In the following, every example of sexual violence in the statute of International Criminal Court is explained.

\subsubsection{Rape}

Of various examples of sexual violence, rape is the most salient instance of violence against women through centuries of hostilities, which nowadays is considered as an example of war crimes, crime against humanity and "in specific conditions, is an example of torture" (Furundzija Case, 1998, 171, cf. Akhgari Bonab, 2009, 200).

Rwanda criminal court defined rape as follows: "physical and sexual violence against a person under conditions which is forceful and using force" (Akayesu Case, 1998, 596; Akhgari Bonab, 2009, 205). Of course applying force does not require to be accompanied with physical pressure; however, threatening, intimidation, extortion and violence and other forms of compulsion which subject the victim to horror and disappointment can lead to compulsory situation. In addition, compulsion might be intrinsic in particular situations like armed conflicts and curfew in which the victim finds him/herself.

International Criminal Court for former Yugoslavia accepted the following factors as the crime of rape "1. sexual penetration, though not deep: a) in the victim's anus (the person being raped) by the sex organ of the doer or any other object used by the doer. b) in the mouth of the person being raped by the doer's sex organ. 2 . by compulsion or force or threatening to force against the victim or the third person (Furundzija Case, 1998, 185; Akhgari Bonab, 2009, 206).

\subsubsection{Sexual slavery}

In definition, sexual slavery means "the doer grants to himself possession right over the other person by acts like buying and selling, renting, exchange and the like, forcing them to do sexual acts" (Mirmohammadsadeghi, 1998). Accordingly, the most salient example of sexual slavery through history is "comfort women" centers established by Japan's armed 
forces during World War II. The more recent examples were "rape camps" set up by the Serbs in former Yugoslavia.

According to the opinion of the Primary Commission of the statute of International Criminal Court the elements of this crime consist of " 1 . The accused has applied the authority resulting from possession right in the case of one or some persons; for instance, he has taken action to sell or buy, lend or exchange persons or has imposed deprivation of liberty on them; 2. The accused has forced a person or persons to do act or acts of sexual nature".

\subsubsection{Enforced prostitution}

Some texts and sources know a lot of the examples of enforced prostitution as overlapping with sexual slavery; however, the outstanding feature of enforced prostitution, which distinguishes it from sexual slavery, is the presence of financial or non-financial advantage created for the doer of the crime of forcing to prostitute or other person, or is expected to gain in the exchange or in relation with the acts of the person being raped. This issue has been clearly stipulated in the draft of Rome Statute of International Criminal Court in 1998: "the crime of enforced prostitution may include a situation which has not reached slavery but the person has surrendered to sexual acts in that situation to be immune from the following injuries or to get something necessary for his rescue (Dayhim, 2001).

In general, it can be said that "forcing to prostitute is a form of sexual slavery in which the element of financial or non-financial benefits of the accused or the other persons is added to the public elements of sexual slavery" (Kittichaisaree, 2010). Also, the elements of enforced prostitution, according to the draft of International Criminal Court, consist of "1. The doer, by force or threatening to use force or compulsion has made a person or persons carry out an act or acts of sexual nature; 2. The doer or other person, in exchange for or in relation with acts of sexual nature has acquired financial benefits or other advantages, or was expected to acquire".

\subsubsection{Forced pregnancy}

Forced pregnancy is of those war crimes which has no record in Additional Protocol II (1997) and article 8 of the statute, as defined in article 7 of the very same statute, puts it among the major violations of rules and customs of war in domestic armed conflicts (Momtaz \& Ranjbaran, 2008).

According to article 7(2), the crime of forced pregnancy includes "illegal imprisonment of a woman who has forcefully been pregnant with the aim of affecting the ethnic combination of a population or other salient acts of violation of international law. This definition must not be interpreted in any way in a way that affects the countries' domestic law concerning pregnancy." This constraint clarifies that prohibition of forced pregnancy does not limit the states' authority to control birthrate and the execution of abortion according to their religion and constitution (Akhgari Bonab, 2009).

According to the draft of the statute of International Criminal Court, the main elements of forced pregnancy consist of " 1 . the accused has detained one or more women; 2. the above woman or women have forcefully been pregnant; 3. the accused was going to keep the woman or women pregnant to change a population combination or to commit another important violation against international law".

\subsubsection{Enforced sterilization}

Due to medical tests conducted against prisoners of war and civilians during World War II as punishment, especially in the camps of forced labor, this crime has been subject to opposition and disapproval. Sterilization without consent can be interpreted as genocide when committed with calculated purpose to annihilate all or a part of people of a group.

Regarding the proposed elements of this crime in the draft of the Primary Commission for International Criminal Court, enforced sterilization can be defined as follows: "the accused deprives a person of the possibility of biologic reproduction and intercourse without any medical reason and without his/her consent. The consent resulting from trick and deception is not acceptable at all. In addition, the temporary measure to control population growth are not subject to this law" (Mirmohammadsadeghi, 1998).

\subsubsection{Any other sexual violence of this same proportion}

By including this paragraph, the regulators of the statute have sought to bring all forms of sexual violence which were not stated in article $7(\mathrm{~g})$ under inclusion of the statute, that is, any kind of violence applied for the sake of sexual purposes or passionate aims are subject to crimes against humanity.

According to the draft of the Primary Commission for the International Criminal Court, the specific elements of 
sexual violence include: 1. the doer has committed an act of sexual nature against a person or persons, or by the use of force or compulsion has caused such person or persons to do an act of sexual nature such as fear of violence, force, detention, mental oppression, or abuse of power against such person or persons by using a compulsory setting or by using such person or persons' inability to give real consent; 2 . The above conduct should have the intensity comparable with other crimes mentioned in the paragraph; 3 . the doer was aware of the real conditions and situation creating the intensity of the act."

\subsubsection{Other similar inhumane acts}

The term "other inhumane acts" was used for the first time in paragraph 3, article 6 of the statute of Nuremberg Trial and ever since this paragraph has been considered in different documents. Maybe the main reason of using this term in different documents was to ascertain that there is no violation in the law concerning classifications and terms of crimes against humanity. In other words, this term demonstrates that the list of the acts stipulated in these documents is not comprehensive and widespread (Akhgari Bonab, 2009, 213).

According to Primary Commission of Rome Statute of the International Criminal Court, the specific elements of "other inhumane acts" include "1. By inhumane acts, the doer causes huge suffering or serious injury to the person's body or his/her physical or spiritual health; 2. The above acts have similar features with the acts mentioned in paragraph 1 , article 7 of the statute; 3 . The doer is aware of the real situation which stabilized the feature of the act".

\section{Findings and Discussion}

Considering the fact that despite various legal support (as it was mentioned in the two public terms and the eleven specific terms) in conventions, resolutions and the reports of international organizations and bodies, not only violence against women in domestic and international hostilities has not stopped but it also is increasing. In this study three fundamental questions are asked. First, what are the kinds of law and support mechanisms for women in international documents and treaties? Second what are the examples of violation of women's rights in recent conflicts? Third, are the current support mechanisms capable enough of protecting women at the time of armed conflicts? In previous sections, effort was made to answer the first and second questions in a clear manner. The answer to the third question is also implied in the sections. In this section, effort is made to answer more exactly the third question.

As it was pointed out in the quotation of the Secretary General in the beginning lines, violence against women "continues" to persist in the world. The emphasis on the word "continue" suggests that despite "the significant development" of many countries in "changing law, policies, functions and approaches" concerning battling violence against women, this "systematic and prevalent human rights abuse" has remained in the world, particularly in domestic and international conflicts. Accordingly, the third question can be altered in this way: why are current support mechanisms in armed conflicts not capable of providing women with the necessary protection? Considering this study and previous studies, a part of the answer lies in the diction wisely used by the Secretary General: "curtain of tolerance". To be more exact, "there have remained a lot of acts so that the curtain of tolerance that sometimes covers violence against women is torn apart."

As we know, facts like recent wars and the quality of providing or not providing humanitarian support of civilians, especially women, depends on controlling abundant variables including cultural factors (beliefs, principles, and national norms), psychological factors (policy-makers' tendencies and spirits), international factors (location and regional and international ties), social factors (national manner, ethnic structure, social history, minorities' situation, gender relations) and political factors (government's structure and history, state/nation relations) and also the relation between these factors.

Although there has been significant development throughout the world in decreasing sexual violence against women, particularly approval of the Statute of International Criminal Court and inclusion of most of the examples of sexual violence, women and girls are still subject to various sexual assaults and the conflicting parties exploit sexual violence against women as a weapon (See recent cases in Congo, Syria and Iraq). Advice and proposed solution in this regard is to teach people, women in particular, around the world to state such incidences without any fear, in case of happening, so that by legal prosecution of the doers of these crimes reoccurrence of such calamities is prevented. The question that comes up is that considering the above variables especially cultural and social ones, how realistic is this expectation from domestic and international wars, specifically those occurring in Asian and African countries? What causes lack of evidence in this regard originates from this very fact. Therefore, with emphasis on showing effective reactions when the crime is committed (acts of violence committed against women); we must help to increase public 
awareness in this regard. To do so and apart from measures of the state (at national level) and the pertaining organizations (at international level), "reinforced participation" is required on the part of private sector and civil society. The aim of these measures can be enabling women.

\section{Appendix}

Statutes, Conventions, and Resolutions of the United Nations

Control Council Law, No 10. Berlin, 30 August 1945

Convention (II) With Respect to the Laws and Customs of War on Land, the Hague, 29 July 1899

Convention (IV) Respecting the Laws and Custom of War on Land, the Hague 18 Oct, 1907

Convention against Torture, and Cruel, Inhuman and Degrading Treatment and Punishments, 1984

ILO. Convention. Concerning Forced or Compulsory Labor, 1930

PCNICC/2000/1/Add. 2

The Nuremberg Tribunal Charter, 1950

The Statue of The International Criminal Tribunal for the former Yugoslavia (ICTY), 1993

The Statute of International Criminal Court. Rome, 1998

The Tokyo War Crimes Tribunal Charter, 1946

UN.DOC. S/18852/ 8 May 1978

UN.DOC. S/18986/17 July 1978

\section{References}

Akhgari Bonab, N. (2009). Criminalization of sexual violence in the statute of international criminal court. Journal of Islamic Law, 23, 191218.

Azizi, B. (2014). The freed body of women in battleground. Retrieved from http://bidarzani.com.

Dayhim, A. (2001). An introduction to international criminal law. Tehran: Foreign Affairs Ministry Publication, $1^{\text {st }}$ Edition.

Fleck, D. (2012). The handbook of humanitarian law in armed conflicts (S. G. Zamani, \& N. Saed, Trans). Tehran: The Institute of Legal Research and Studies Publication, 2nd Edition (Original work published in 2009).

Ghorbannia, N. (2011). Human right and humanitarian law. Tehran: The Research Center of Culture and Islamic Thoughts Publication, $2^{\text {nd }}$ Edition.

Henckaerts, J. M., \& Doswald-Beck, L. (2008). Customary international humanitarian law (Judiciary Office of International Affairs and International Committee of the Red Cross Trans). Tehran: Majd Publication, 1 st Publication (Original work published in 2005).

Henderson, C. W. (2010). Understanding international law. Oxford: Wiley-Blackwell.

Khak, R. (2008). Criminalization of sexual violence in international criminal law. International Journal of Law, 25 (39), 101-146.

Kittichaisaree, K. (2010). International criminal law (H. Aghayi Jannatmakan, Trans). Tehran: Jungle Publiction, $3^{\text {rd }}$ Edition (Original work published in 2001).

Krill, F. (2008). The protection of women in international humanitarian law (M. H. Baghi, Trans). Tehran: Govahan Publication, 1st Edition (Original work published in 1985).

Mirmohammadsadeghi, H. (1998). International criminal law. Tehran: Mizan Publication, $1^{\text {st }}$ Publication.

Momtaz, J., \& Ranjbaran, A. H. (2008). International humanitarian law: The law of internal armed conflicts. Tehran: Mizan Publication, $3^{\text {rd }}$ Edition.

Mo'zenzadegan, H. A., Heidari, M. A., \& Nikoomanzari, A. (2013). Armed conflicts and violence against women and children in accordance with international regulations. Quarterly Journal of Women and Culture, 5 (17), 9-20.

Pourmohammadi, N. (2012). Humanitarian law in Iraq-Iran war. Tehran: Hastinama Publication, 1st Edition.

Ramezani Ghavamabadi, M. H. (2010). The role of international committee of red cross in creating and executing non-international armed conflicts. Tehran: Khorsandi Publication, $1^{\text {st }}$ Edition.

Solis, G.D. (2010). The law of armed conflict: international humanitarian law in war. New York, Cambridge: University Press.

Visniec, M. (2012). The body of a woman as a battlefield in the Bosnian War (T. Razmjoo, Trans). Tehran: Ney Publication, $5^{\text {th }}$ Edition (Original work published in 1997).

Zaheri, A. (1998). Distinction between civilians and military personnel in international armed conflicts and its comparison with the Islamic Republic of Iran Army, Monthly Journal of Trial Advocacy, 11, 58-62.

Zamani, S. G. (1999). International humanitarian law and occupation of Iranian lands in the Forced War. Journal of Defense Policy, 28, 33-60.

Ziaie Bigdeli, M. R. (2001). War law. Tehran: Allameh Tabataba'i University Publication, 2nd Edition.

Ziaie Bigdeli, M. R. (2013). International humanitarian law. Tehran: Ganje Danesh Publication, 1'st Edition. 